\title{
Offender Characteristics: A Study of 23 Violent Offenders in Sweden
}

\section{Ardavan Khoshnood \& Marie Väfors Fritz}

To cite this article: Ardavan Khoshnood \& Marie Väfors Fritz (2016): Offender Characteristics: A Study of 23 Violent Offenders in Sweden, Deviant Behavior, DOI: 10.1080/01639625.2016.1196957

To link to this article: http://dx.doi.org/10.1080/01639625.2016.1196957

$$
\text { Published online: } 01 \text { Jul } 2016 .
$$

Submit your article to this journal $₫$

Llll Article views: 79

Q View related articles $\sqsubset$

View Crossmark data ¿ 


\title{
Offender Characteristics: A Study of 23 Violent Offenders in Sweden
}

\author{
Ardavan Khoshnood (D) and Marie Väfors Fritz
}

Malmö University, Malmö, Sweden

\begin{abstract}
Twenty-three offenders convicted of homicide or attempted murder/manslaughter, and their respective crimes, were examined to identify any common characteristics. Court documents were assessed, and the most prominent information of the offenders was that they were often single, most of them had no psychiatric diagnoses, the most frequent modus operandi was a knife or sharp weapon (although firearms resulted in more homicides), and the most common homicide typology was domestic disputes, and disputes between friends or acquaintances. Based on a cluster analysis, two profiles emerged: one with so-called traditional criminals and another profile over-represented with offenders who commit domestic crimes.
\end{abstract}

\section{ARTICLE HISTORY}

Received 30 October 2015

Accepted 26 January 2016

\section{Introduction}

In the last ten-year period, deadly violence in Sweden, defined as murder, manslaughter, child homicide, and involuntary manslaughter through assault, fluctuated between 68 and 111 cases each year (Brottsförebyggande rådet 2015). Murder/manslaughter is thus relatively uncommon in Sweden; however, if measured per capita, the picture that emerges looks somewhat different. For instance, in 1998, two murders/manslaughters were committed per capita in Sweden, which is a higher incidence rate than in other countries such as the Netherlands, Greece, Canada, Germany, England and Wales, Denmark, and Norway (Bijleveld and Smit 2006). Common or not, lethal violence such as murder and manslaughter has far-reaching consequences (tangible and intangible costs) and warrants extended research (Brad, Coupland and Olver 2014; Cohen and Piquero 2009; Miller, Cohen, and Wiersema 1996).

Having knowledge of offender characteristics can contribute to more resourceful investigations, as it may help professionals narrow their search for offenders. Ainsworth (2001) defines the profiling process as "[the] process of using all the available information about a crime, a crime scene, and a victim in order to compose a profile of the [...] unknown perpetrator" (p. 7) This does not reveal who the offender is to the investigators, but rather, it reveals the characteristics an offender is likely to have. As stated by Canter (2011), referring to profiling equations, "[they] serve to summarize the search for consistent associations between aspects of a crime and features of the criminal that will be useful to investigations" (p. 5). Therefore, the question of who commits the crime is of primary interest.

Unfortunately, most of the studies on offender characteristics are based on Anglo-Saxon studies and literature. Only one study (Liem et al. 2013) has been identified that studies offender characteristics in the more specific context of those who commit homicide in Sweden. 
The present study will conduct a detailed analysis of offender characteristics of those convicted for murder/manslaughter or attempted murder/manslaughter in a city in Sweden between the years of 2009-2013. This time period was chosen because the cycle of operation at the country's District Courts, means that all the material at the Courts can be eliminated after five years, including all the pre-trial material (Riksarkivet 2010). Further, the District Court's computer system registry can only search five years back in time, meaning the cases are no longer searchable by the registry after five years (Domstolsverket 2007; Malmö tingsrätt 2010).

Our research questions consist of the following: What are the characteristics of the offenders convicted of these violent crimes? And, based on these characteristics, can one or more profiles be identified?

This study will present one or more patterns of offender characteristics, i.e. profiles, which will give an image of those who commit murder/manslaughter or attempted murder/manslaughter. The identified attributes held in common for the present cases may also be of use in various risk assessments. Furthermore, this study may contribute to more specific knowledge of these offenders, which is of importance for both profilers in the police force and the police's criminal intelligence organization (Kocsis 2003; Sparrow 1991).

\section{Characteristics}

Langevin and Handy (1987) deem that factors surrounding a homicide reveal certain characteristics of the offender. In addition to offender characteristics, descriptions of the crime and the victim give a wider and more complete picture of the criminal process (Holmes and Holmes 2009).

\section{Offender characteristics}

According to Messner and Rosenfeld (1999), sex and age, together with race and social class are the main factors correlated with homicide. Furthermore, in discussions of offender characteristics, marital status is also widely studied.

The offender's mental health prior to or at the time of the crime is also of interest, especially because certain psychiatric disorders have been seen to be highly correlated to violent crimes (Howitt 2009; Langevin and Handy 1987; Teplin 1984; Torrey 2011). In a study of over 20,000 prisoners in 12 prisons of various countries, Fazel and Danesh (2002) show that the majority of the prisoners suffered from serious psychiatric disorders. The characteristic of mental health in the present study involves, among other things, whether the offender had been sentenced to forensic psychiatric care, thus tapping into whether or not the offender suffers from a serious mental disorder.

Level of education is another characteristic often discussed as a risk factor for violent behavior. Aside from education affecting these individuals' routine activities, schools and educational institutions also have a major crime preventive function (Gottfredson, Wilson, and Skroban-Najaka 2006). Further, many studies have shown previous crime to be a risk factor for recidivism and that most offenders have a history of crime (Cornell 1990; Gabor and Gottheil 1984; Gottlieb et al. 1990; Langevin and Handy 1987; Pridemore 2006). In addition, substance abuse and employment are both associated with offending, and both are important when it comes to adapting to social norms and routine activities (Bijleveld and Smit 2006; Chaiken and Chaiken 1990; Cornell 1990; Tita and Griffiths 2005).

The last offender characteristic examined in the present study is the offender's socioeconomic status (SES). Several studies provide evidence of a robust correlation between low SES and crime in general (e.g., Gottlieb et al. 1990; Meier and Miethe 1993; Savage 2009), and violent crime specifically (Aaltonen et al. 2012; Bijleveld and Smit 2006). In this present study, employment is used to measure the offenders SES because the offender's occupation or occupational status is referred to often in the court documents and thus available to us.

In international literature, factors such as race, IQ, family history, religion, and military service also serve as important information (Bijleveld and Smit 2006; Decker 1993, 1996). These and other 
characteristics are not included in the present study because this information was unavailable to the authors.

\section{Victim characteristics}

The material used for the study is mainly concentrated on the offender and the offense and contains little information about the victim. As a result, several potentially interesting characteristics of the victim could not be derived from the material used. However, as evident in the literature, two of the most well-studied (Jensen and Brownfield 1986; Liem et al. 2013; Pridemore 2006; Salfati and Canter 1999; Zahn and Sagi 1987) victim characteristics were visible in our material; sex and age. These two characteristics are briefly presented as descriptives in the results section.

\section{Crime characteristics}

Characteristics of the crime lie in the center of the deductive profiling method (Holmes and Holmes 2009). The foremost interesting characteristic to study is the modus operandi, which is defined as how an offender carries out their crime(s) (Howitt 2009). In several studies, modus operandi has been equated with the victim's cause of death/how the victim is attacked (Bijleveld and Smit 2006; Liem et al. 2013; Zahn and Sagi 1987), which is also mimicked in this present study. The most common modus operandi in Sweden are with firearms and knives, depending on where in Sweden the crime is committed (Ekström et al. 2012).

Homicide typology is also an important crime characteristic. In some studies, it is defined as the relationship between the offender and the victim (Cornell 1990), while in other studies, it is defined by the offender's motive (Crabbé, Decoene and Vertommen 2008, Zahn and Sagi 1987). Often, motive and the relationship between the offender and victim merge. Therefore, in this present study, homicide typology is described by both the motive and offender-victim relationship. An example of homicide typology is "domestic dispute", defined by Liem and colleagues (2013) as crimes by intimate partners or other forms of family-related crimes.

Another characteristic studied is the scene of crime, which is the exact spot where the crime occurred. Liem and colleagues (2013) discuss the crime scene in a simple, but clear manner thereby avoiding complex and unnecessarily long explanations and subheadings, something that unfortunately pervades other studies. The locations for this characteristic are "private" or "public." The definition is as follows (Liem et al. 2013): "[...] 'public' reflecting public locations such as parks, forests, recreational areas, shops, restaurants, bars, streets, public transportation or the workplace; 'private' including the private home of either the victim or offender, a hotel, motel, dormitory or car" (p. 82).

The last characteristic discussed in the present study, which many other studies have also looked at (Langevin and Handy 1987, Pridemore 2006), is whether or not the offender and/or the victim was intoxicated with alcohol and/or illegal drugs ${ }^{1}$ at the time of the crime. The relationship between intoxication and crime has been clearly shown, and therefore, this issue is of great interest. For example, alcohol is involved in some way in half of the murder cases discussed by Langevin and Handy (1987). Intoxication is defined as when the offender/victim in connection to the crime is under the influence of alcohol and/or illegal drugs.

\section{Method}

The purpose of the present study is to investigate cases where individuals in a metropolitan city in Sweden have been convicted of murder, manslaughter, attempted murder, or attempted manslaughter. These cases are carefully analyzed to identify various offender characteristics to develop one or more profiles.

${ }^{1}$ Illegal drugs are defined here as illegal substances and/or medication not prescribed to the individual. 


\section{Participants}

Only cases consisting of offenders convicted of murder/manslaughter or attempted murder/manslaughter between the years of 2009-2013 in a metropolitan city in Sweden were included in the study. All of the offenders were given the opportunity to leave this study, but no one withdrew. The cases of involuntary manslaughter were excluded because it is a crime in which the offender had no intention of killing the victim, unlike that of murder and manslaughter. Of the cases that were included for further analysis, one outlier has been excluded because it is distinguished by serial violent offenses with lethal intent. Serial offenders have other motives and etiology in comparison with offenders who are not classified as such (Forsyth 2015, Haggerty 2009, Holmes, De Burger, and Holmes 1988). The inclusion of this particular case would have contributed to the greatly increased variability of the data and, as the generating mechanisms (inferred cause) are different in this case, it was appropriate to exclude it to illustrate more accurate patterns (Barnett and Lewis 1994; Hawkins 1980).

Female offenders were also excluded from the study because the amount of female offenders who had committed these types of crimes during the chosen period was too few, and the risk of their respective identification would thus increase.

We identified 19 cases which included 23 offenders and 19 victims. Of the 19 identified unique cases, there were multiple offenders in three of them. None of the cases contained multiple victims. In 13 of the cases, the offenders were convicted of murder, none convicted of manslaughter, and three convicted of attempted murder and attempted manslaughter respectively.

In 14 of the cases, the offenders appealed the District Court's ruling in the Court of Appeals. In only one case was the offense changed to a milder offense in the Court of Appeals; nonetheless, it remains one of the crimes included in this study. In eight cases, the Court of Appeals modified the sentence. In four cases, a more severe penalty than what the District Court had originally sentenced the accused was handed down, and in the other four cases, the Court of Appeals sentenced the offenders to a more lenient punishment.

In 10 cases, 11 offenders had undergone a $\$ 7$-examination and/or a forensic psychiatric examination $^{2}$. Based on these examinations, two offenders were sentenced to forensic psychiatric care. Of the remaining 21 offenders, three were sentenced to youth custody from 1.6 to 3 years. Eighteen offenders were sentenced to an average of 13 years in prison. One prison term of 18 years was awarded. In two of the cases, the offenders were also sentenced to expulsion from the country.

\section{Material}

The use of court documents in criminological research is common and well proven (King and Wincup 2008), thus many documents from the District Court and the Court of Appeals were used in this study. It is important to point out that only some parts of these documents were of significance; these were the parts of the text where offender and victim characteristics, as well as the actual crime, were described and discussed.

Relying on the official crime statistics of lethal violence has shown to be somewhat questionable (Loftin et al. 2015; Rying 2003), not least because some unnatural deaths which, in fact, may have been caused by a crime are missed because the physicians may not have reported the case to the police (Pettersson and Eriksson 2013); thus, the present study relies only on actual court documents.

All available documents in the court file were retrieved. The court files include such information as the verdict, the police criminal investigation as well as the forensic investigation. Documents covered by the Swedish confidentiality law, including among others, the forensic psychiatric examinations in all cases

\footnotetext{
${ }^{2}$ The offender's mental state is of great importance when a court determines that he is guilty of a crime in which he can be sentenced to prison. According to Swedish law, an offender who may suffer from a serious mental disorder at the time of the crime and/or the time of the psychiatric examination can be sentenced to forensic psychiatric care instead of prison. This full psychiatric examination usually precedes a smaller so-called §7-examination in which a psychiatrist assesses whether a full forensic psychiatric examination is needed.
} 
where the offender had undergone one, have not been available for review. However, the first page of this particular examination was available; it shows whether or not the offender was suffering from a serious mental disorder at the time of the crime and/or time of the examination and is thus included in the analyses.

\section{Procedure}

The local ethical review board has approved the study (D. nr. 2014/50). After contact with the District Court, in accordance with the Swedish "Freedom of Information" law, a list of those convicted for murder/manslaughter or attempted murder/manslaughter was created and their court documents compiled. Every case was further investigated to see if the District Courts decision was appealed by either the defendant or the prosecutor.

After coordination with both the District Court and the Court of Appeals, 19 cases were identified where at least one perpetrator was convicted of murder, manslaughter, attempted murder or attempted manslaughter. These 19 unique cases include 23 offenders and 19 victims.

After all the documents from the respective cases had been collected, they were systematically examined and analyzed, which is an important step in document analysis (Bowen 2009).

\section{Data analysis}

As a first step, the data analysis followed a systematic approach using document analysis which includes principles of decontextualization (Malterud 2009) where relevant parts of the documents have been taken out of context and studied closely in conjunction with text related to the same phenomena in order to study patterns and individual attributes as a phenomena (Altheide et al. 2010; Bowen 2009; Wesley 2010) using a matrix of similar characteristics. Once the matrix had been completed, the content, largely composed of text, was encoded into numbers and exported to SPSS.

Thus, the second step included a K-means cluster analysis of the offender characteristics and crime characteristics. Cluster analysis is commonly used in criminological research (Esbensen and Huizinga 1993; Grubesic and Murray 2001; Hindelang and Weis 1972; Kalichman 1988; Neema and Böhning 2010) and involves systematizing data into schematic groups/clusters (Hartigan 1978; Johnson 1967; Ward 1963).

\section{Results}

\section{Victim descriptives}

Of the 19 victims in the present study, 14 were men and five were women. Age was derived from the victims' social security numbers which contains their date of birth and is available in the court files. The average age and the median age of the victims is 39.1 respective 39 and ranged between 17 and 74 years old.

\section{Offender characteristics}

The average age and the median for the 23 included offenders is 32.8 and 29 years old, respectively, with a range from as young as 15 to 59 years old. Three of the offenders were minors when the crime was committed. If distributed in groups of ten, the majority of offenders are in the age group 21-30 and then the age group 41-50.

Regarding marital status, 16 of 23 offenders were "single" at the time of the crime, four were "separated/divorced" and single at the time of the crime, and three were "married."

In regard to mental health, interestingly, the majority of the offenders had "no psychiatric diagnosis" prior to, or at the time of, the crime. Two were "sentenced to forensic psychiatric care" showing they had a serious mental disorder. Seven had, or still has, "a psychiatric diagnosis"; 
however, not one that is so serious that they cannot be sentenced to prison. In only one case was the offender's mental health "unknown."

Level of education for nine offenders was "unknown." One offender had "no education" at all, and nine had only "compulsory schooling." Three had completed "secondary education," while one had a "vocational education." None of the offenders had a "university education or degree."

The offender's criminal record indicating prior crime is almost always available for the court and thus a part of the police investigation. For one offender, however, this information was "unknown" due to his recent settlement in Sweden. For three offenders, "no record of prior crimes" existed. Nineteen of the offenders had previous criminal records; six offenders had, in the past, been found guilty for "offenses other than violent offenses," while 13 had been found guilty of both violent and "non-violent crimes."

The question of substance abuse has been one of the more difficult characteristics to investigate because it is rarely discussed in the reviewed documents. Therefore, this is "unknown" for seven offenders. Ten offenders were found to have had an "abuse problem." Of the six remaining offenders, none of them had any record of problems in terms of abuse.

Consistent with previous research about occupation and socioeconomic status (SES), we see that the majority of the offenders were "unemployed" at the time of the crime. Four offenders were receiving "social welfare." For two of the offenders, it has not been possible to determine their SES from the available documents. Of the remaining 21 offenders, five were employed and 16 termed "unwaged labor."

Offender characteristics are presented in both prevalence and percentage in Table 1.

Table 1. A presentation of the studies offender characteristics.

\begin{tabular}{|c|c|c|c|}
\hline \multicolumn{2}{|l|}{ Offender characteristics } & \multirow{2}{*}{$\begin{array}{c}\text { Prevalence } \\
23\end{array}$} & \multirow{2}{*}{$\frac{\text { Percent }}{100}$} \\
\hline Sex & Male & & \\
\hline \multirow[t]{5}{*}{ Age } & $11-20$ & 3 & 13 \\
\hline & $21-30$ & 9 & 39 \\
\hline & $31-40$ & 2 & 9 \\
\hline & $41-50$ & 8 & 35 \\
\hline & $51-60$ & 1 & 4 \\
\hline \multirow[t]{3}{*}{ Marital status } & Single & 16 & 70 \\
\hline & Married & 3 & 13 \\
\hline & Separated/divorced & 4 & 17 \\
\hline \multirow[t]{4}{*}{ Mental health } & Sentenced to forensic psychiatry & 2 & 9 \\
\hline & No psychiatric diagnosis & 13 & 57 \\
\hline & Psychiatric diagnosis & 7 & 30 \\
\hline & Unknown & 1 & 4 \\
\hline \multirow[t]{5}{*}{ Level of education } & No education & 1 & 4 \\
\hline & Compulsory education & 9 & 39 \\
\hline & Secondary education & 3 & 14 \\
\hline & Vocational education & 1 & 4 \\
\hline & Unknown & 9 & 39 \\
\hline \multirow[t]{4}{*}{ Prior crime } & No record of prior crime & 3 & 13 \\
\hline & Prior crime, other & 6 & 26 \\
\hline & Prior crime, other and violent crime & 13 & 57 \\
\hline & Unknown & 1 & 4 \\
\hline \multirow[t]{3}{*}{ Substance abuse } & No record of abuse & 6 & 26 \\
\hline & Abuse & 10 & 44 \\
\hline & Unknown & 7 & 30 \\
\hline \multirow[t]{8}{*}{ Employment } & Other & 2 & 9 \\
\hline & Employed & 3 & 13 \\
\hline & Student & 3 & 13 \\
\hline & Unemployment fund & 1 & 4 \\
\hline & Unemployed & 5 & 22 \\
\hline & Sickness benefit & 3 & 13 \\
\hline & Social welfare & 4 & 17 \\
\hline & Other & 2 & 9 \\
\hline \multirow[t]{3}{*}{ Socioeconomic status } & Working & 5 & 22 \\
\hline & No wage labor & 16 & 69 \\
\hline & Unknown & 2 & 9 \\
\hline
\end{tabular}




\section{Crime characteristics}

In regard to modus operandi, 10 of the offenders had, at the time of the crime, used a "knife or sharp weapon," which constitutes the majority of cases, closely followed by "firearms" used by eight offenders. Two offenders fall under the category "other": both had given a gun to another offender who then used it against the victim. However, they were both convicted in accordance with the District Court's rule because they acted together and in consensus with the offender's use of the weapon.

When comparing the modus operandi and the offense, we can see that in the cases where firearms were used, it led to a more lethal outcome compared to those of knives or other sharp weapons.

Regarding Homicide typology (Figure 1), of the majority of the cases, six are termed "domestic disputes" (also known as family tragedies). We found a "psychotic deed" in only one case, wherein the offender and the victim had not previously known each other. This deed could very well have been categorized as a "stranger deed," but the forensic psychiatric examination showed that the offender committed the crime with a severe mental disorder and because the court's rule also focuses on the offender's mental health, the homicide typology of "psychotic deed" was used. However, in one of the other cases, the term "stranger deed" was used because the offender and victim had not previously known each other. One case is categorized under "other," as the offender committed the crime against the wrong person in what is called error in persona. In three cases, this characteristic is "unknown."

The question of homicide typology in relation to modus operandi shows that "knives or sharp weapons" are most prevalent in most of the typologies. "Firearms" are, perhaps not surprisingly, over-represented in gang-related crimes.

The scene of crime has been available in the documents we have analyzed for all of the 19 studied cases. The distribution of this characteristic is relatively even; nine cases categorized under "private" and in 10 cases, under the category "public."

To determine whether the offender and/or the victim were intoxicated at the time of crime has been quite challenging, especially in regard to the offenders. In the majority of the cases, this is because the offender is sometimes arrested after several hours, or even days or weeks later. In this case, a chemical analysis would be of no value for the criminal investigation. Another reason is that, in some cases, the police for unknown reasons have failed to take blood and urine samples for further chemical analysis. It is "unknown" whether 15 offenders were intoxicated or not at the time of the crime. Only eight offenders can be assessed in this regard: six were "intoxicated during the crime," and two were "not intoxicated during the crime."

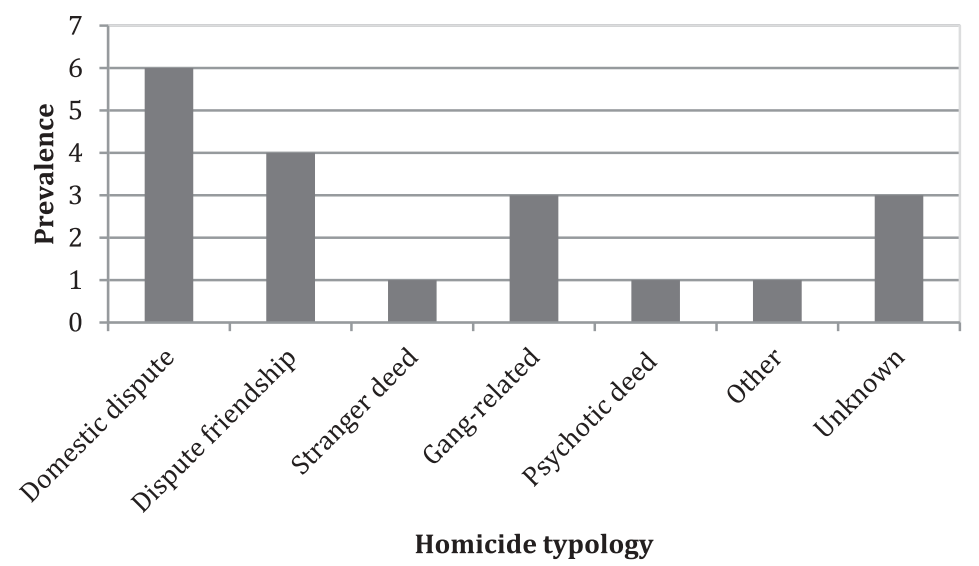

Figure 1. Prevalence of the offender's homicide typology. 
Unlike the offenders, it was easier to compile information regarding "intoxication at the time of the crime" when discussing the victim because, if killed (as the majority of the cases in this present study were), they undergo a forensic chemical examination at the forensic autopsy. Of the victims, it is for four of them "unknown" whether they were intoxicated or not at the time of the crime, 10 were "not intoxicated," and five were found to be "intoxicated at the time of the offense."

\section{Cluster analysis}

With the help of K-means cluster analysis, two profiles of offender types were identified: Profile A, consisting of 13 offenders and Profile B, consisting of 10 offenders. The following characteristics were shown to be significant for the individuals in the respective profiles: marital status $\left(0.043^{\star}\right)$, mental health $\left(0.001^{\star * *}\right)$, modus operandi $\left(0.022^{\star}\right)$, homicide typology $\left(0.012^{\star}\right)$, and if the offender was intoxicated at the time of the crime $\left(0.030^{*}\right)$.

Profile A shows that the offender is between 15-33 years old and single. He has no previous psychiatric diagnosis and mainly primary school education. He does not work; thus, he is either a student, unemployed, or is supported by social welfare. He has been previously convicted of offenses, including violent offenses. He uses firearms in his criminal activity, which is most often gang-related. The crime scene is usually public, and in most cases, the victims are intoxicated at the time of crime.

Profile B shows that the offender is between 37-59 years old and single. He has a previous psychiatric diagnosis, and in comparison with offenders in Profile A, he is better educated. He is primarily on disability pension and not working. He also has an addiction problem, and has previously been convicted of a crime, including violent crime. He mainly uses a knife or other sharp weapon in his deeds and has a clear relationship with the victim. The crime scene is mainly private, and in most cases, the victims are not intoxicated during the crime.

Offender characteristics for the two profiles are presented in Table 2.

\section{Discussion}

The purpose of this study is to investigate the common characteristics of a sample of violent offenders (Table 1). The following characteristics were significant in both profiles: marital status, mental health, modus operandi, homicide typology, and if the offender was intoxicated at the time of the crime. Most of the offenders in both profiles were "single." When it comes to mental health, however, the offenders in Profile B are much more likely to suffer from a psychiatric condition and be sentenced to "forensic psychiatric treatment." Regarding modus operandi, "knives and sharp weapons" were used by offenders in both profiles. "Aggravated assault" is observed more in Profile B and "firearms" more in Profile A. What differs among the profiles is that offenders in Profile B engaged in "domestic disputes" or had been friends with, or were in other ways associated with their victims. The only exception to this is one offender included in Profile B; he fits in this profile because he shares the same characteristics with the other offenders in that group: modus operandi (knife), mental health (sentenced to forensic psychiatric care), and employment (sickness benefits). Regarding intoxication at the time of the crime, this is "unknown" for most of the offenders. The material only provides information about intoxication in eight cases, wherein six tested positive. To draw any conclusions based on these eight offenders is difficult; yet, that so many of the offenders were intoxicated falls well in line with previous studies that show the proportion of intoxication in violent crimes, including homicide, is between 50-66\% (Farrington and Lambert 2010; Langevin and Handy 1987; Palermo 2010).

The results in the present study supports earlier findings, first, because homicide offenders are often "single" (Anderson and Holcomb 1983; Gottlieb et al. 1990; Langevin and Handy 1987).

Second, and most interestingly, is that even though only nine of the offenders in this study have "a psychiatric diagnosis," they are all in Profile B. Thus, multiple studies have found that psychiatric 
Table 2. Offender characteristics for profile A and B in prevalence.

\begin{tabular}{|c|c|c|c|}
\hline Offender and crime characteristics & & Profile A & Profile B \\
\hline Sex & Male & 13 & 10 \\
\hline \multirow[t]{3}{*}{ Marital status } & Single & 11 & 5 \\
\hline & Married & 2 & 1 \\
\hline & Separated/divorced & 0 & 4 \\
\hline \multirow[t]{4}{*}{ Mental health } & Sentenced to forensic psychiatry & 0 & 2 \\
\hline & No psychiatric diagnosis & 11 & 1 \\
\hline & Psychiatric diagnosis & 1 & 7 \\
\hline & Unknown & 1 & 0 \\
\hline \multirow[t]{5}{*}{ Level of education } & No education & 0 & 1 \\
\hline & Compulsory education & 7 & 2 \\
\hline & Secondary education & 1 & 2 \\
\hline & Vocational education & 0 & 1 \\
\hline & Unknown & 5 & 4 \\
\hline \multirow[t]{4}{*}{ Prior crime } & No record of prior crime & 2 & 1 \\
\hline & Prior crime, other & 3 & 3 \\
\hline & Prior crime, other and violent crime & 7 & 6 \\
\hline & Unknown & 1 & 0 \\
\hline \multirow[t]{3}{*}{ Substance abuse } & No record of abuse & 4 & 3 \\
\hline & Abuse & 4 & 5 \\
\hline & Unknown & 5 & 2 \\
\hline \multirow[t]{8}{*}{ Employment } & Other & 1 & 1 \\
\hline & Employed & 1 & 2 \\
\hline & Student & 3 & 0 \\
\hline & Unemployment fund & 0 & 1 \\
\hline & Unemployed & 3 & 2 \\
\hline & Sickness benefit & 0 & 3 \\
\hline & Social welfare & 3 & 1 \\
\hline & Other & 2 & 0 \\
\hline \multirow[t]{3}{*}{ Socioeconomic status } & Working & 2 & 3 \\
\hline & No wage labour & 9 & 7 \\
\hline & Unknown & 2 & 0 \\
\hline \multirow[t]{4}{*}{ Modus operandi } & Knife/sharp weapon & 4 & 6 \\
\hline & Aggravated assault & 0 & 3 \\
\hline & Firearm & 7 & 1 \\
\hline & Other & 2 & 0 \\
\hline \multirow[t]{7}{*}{ Homicide typology } & Domestic dispute & 1 & 5 \\
\hline & Dispute, friendship/acquaintance & 1 & 4 \\
\hline & Stranger deed & 1 & 0 \\
\hline & Gang-related & 5 & 0 \\
\hline & Psychotic deed & 0 & 1 \\
\hline & Other & 1 & 0 \\
\hline & Unknown & 4 & 0 \\
\hline \multirow[t]{2}{*}{ Scene of crime } & Private & 5 & 6 \\
\hline & Public & 8 & 4 \\
\hline \multirow[t]{3}{*}{ Intoxicated at the time of crime, Offender } & Intoxicated & 2 & 4 \\
\hline & Not intoxicated & 0 & 2 \\
\hline & Unknown & 11 & 4 \\
\hline \multirow[t]{3}{*}{ Intoxicated at the time of crime, Victim } & Intoxicated & 6 & 2 \\
\hline & Not intoxicated & 3 & 2 \\
\hline & Unknown & 4 & 6 \\
\hline
\end{tabular}

diagnoses are common among inmates in prisons (Fazel and Danesh 2002) and well correlated with criminal acts (Langevin and Handy 1987; Teplin 1984; Torrey 2011). However, the results of this study show the absence of psychiatric diagnosis in Profile A. Other studies also confirm this result; many offenders who commit serious violent crimes do not suffer from any diagnosed psychiatric disorders or are declared sane by a court of law (Gillies 1976, Howitt 2009). Other studies have shown that a psychiatric diagnosis is only a random factor in discussing homicide (Langevin et al. 1982; Rosenbaum and Bennett 1986; Scott 1973). Howitt (2009) notes that "For most homicides, there is little to implicate psychiatric factors, which indicates that other factors need to be taken into account." Our results show that "a psychiatric diagnosis" is most common in offenders who 
committed a crime against their current or former partner, or else in disputes between friends or acquaintances and who fit into Profile B. Belfrage and Rying (2004) confirm that a large proportion of these so-called domestic violence offenders have mental disorders.

Third, both modus operandi and homicide typology showed to be significant characteristics. In a comparison between age and modus operandi, we see that when offenders aged 21-30 committed their crimes, they mainly used "firearms." In the same age category, the proportion of "gang-related crimes" was high. These are offenders who mainly occupy Profile A. However, the higher the age, the less likely they are to use firearms. Interestingly, when the crime was committed against a former or current partner or there were disputes between friends or acquaintances, a "knife or sharp weapon" was mainly used, which is evident in those included in Profile B and also confirmed in previous studies (Belfrage and Rying 2004; Dobash, Dobash, and Cavanagh 2009).

In discussing the question of modus operandi in Sweden, Liem and colleagues (2013) argue: "[...] homicides in Sweden to be most likely to be committed with weapons other than with firearms." This view does not fit particularly well in the cases we examined in this present study, given that "firearms" have caused more homicides than "knives or other sharp weapons", although the latter is more common. Thus, "firearms" in this present study caused more homicides, both in terms of prevalence and percentage. One reason for this difference may be that Liem and colleagues included more offenders in their study than was included in this study and that they solely focused on homicide, not attempted murder/manslaughter which is included in our study.

Last, offenders who committed "crimes against a current or former partner" or "disputes between friends or acquaintances", are somewhat older when age is compared with homicide typology. These offenders are mostly found in the 41-60-year-old age group. This can be seen clearly in Profile B, which is primarily representative of these offenders. The reason for this category of offenders being somewhat older probably has to do with the etiology of the crime. In family tragedies where women are subjected to violence by the hand of their past or current male partner, a great deal of emotions are involved and are emotions that have probably taken a long time to develop. Furthermore, children are usually in the picture, which also may indicate a long-term relationship. Palermo (2010) argues that "Spousal homicide usually follows long-standing verbal, psychological, and physical abuse."

The findings regarding homicide typology in the present study are similar to findings in the Netherlands where $32 \%$ and $15 \%$ of all homicides were "domestic disputes" and "disputes between friends or acquaintances" (Bijleveld and Smit 2006). In fact, of the 19 cases studied in the present study, the offender and victim had some kind of relationship with each other in 13 cases. Thus, a clear majority of our offenders and victims have had some kind of previous contact. This finding is also consistent with previous research (see, e.g., Crabbé et al. 2008; Decker 1993; Salfati and Canter 1999). Moreover, the two types of profiles in this present study have similarities with the study conducted by Kalichman (1988) on 118 homicide offenders, giving rise to four types of offenders, one being offenders who commit crimes against a current or former partner (i.e., Profile B in this present study).

In our study, all victims within the typology "domestic dispute," except one, are women. The Swedish Crime Prevention Council states in its report, "Crime and safety in Malmö, Stockholm and Gothenburg: A survey" (Ekström et al. 2012), that the largest categories of lethal force in Sweden's three largest cities of Stockholm, Gothenburg, and Malmö, are disputes among partners in a relationship or former relationship, and disputes between friends or acquaintances.

\section{Limitations}

In geographic terms, the study is limited to a specific city in Sweden. This city is an optimal choice because, for many years, it has been the location of several violent crimes, in terms of both gangrelated activity and so-called domestic dispute violence. The material collected is thus heterogeneous and diverse. However, in this particular city, many unsolved murder/manslaughter and attempted murder/manslaughter cases exist, and this could have possibly changed the outcome and conclusion of this study if they had been tried in a court of law (and thus included in this study). 


\section{Conclusion}

Although certain characteristics stand out, it is important to note that violent crime (including homicide) is multifactorial, complex, and embraces several theories (see, e.g., Gottfredson and Hirschi 1990; Holmes and Holmes 2009; Howitt 2009; Loeber et al. 2005; Palermo 2010). With that stated, the purpose of this study was mainly to be able to produce one or more profiles of offenders convicted of murder, manslaughter, attempted murder, or attempted manslaughter in a metropolitan city in Sweden. As a result of this analysis, two profiles were identified by means of a cluster analysis.

The offenders from the investigated city consisted of both the so-called traditional criminals found in Profile A (younger men using firearms in gang-related activity) and, in contrast, the criminals who were involved in domestic disputes, which was the most common type of crime distinguishing those in Profile B. Having known the victim and having used a knife or sharp weapon are also both characteristics of the offenders in Profile B.

The main contribution of this study is the issue of mental health. This is clearly distinguished between the two profiles, with the majority of the offenders having been given a psychiatric diagnosis or sentenced to forensic psychiatric care found in Profile B. More research is needed to validate the results that traditional criminals in Profile A do not have significant psychiatric diagnoses in comparison to those in Profile B, where psychiatric diagnoses are commonly found.

\section{Notes on contributors}

ARDAVAN KHOSHNOOD is a medical resident in Emergency Medicine at the Skåne University Hospital in Lund. $\mathrm{He}$ is also a Ph.D. student in Clinical Medicine. He also holds a two-year-master of science in Criminology from Malmö University, and a bachelor degree in Intelligence Analysis from Lund University.

MARIE VÄFORS FRITZ holds a Ph.D. in psychology. She is a Senior Lecturer and Director of Studies, at the Department of Criminology, Malmö University. She has conducted research on personality and neuropsychological indicators of vulnerability of antisocial development, aggression, violence, and crime.

\section{ORCID}

Ardavan Khoshnood (D) http://orcid.org/0000-0002-3142-4119

\section{References}

Aaltonen, Mikko, Janne Kivivuori, Pekka Martikainen, and Venla Salmi. 2012. "Socio-Economic Status and Criminality as Predictors of Male Violence: Does Victim's Gender or Place of Occurrence Matter?" British Journal of Criminology 52(6):1192-1211.

Ainsworth, Peter B. 2001. Offender Profiling and Crime Analysis. New York: Routledge.

Altheide, David, Michael Coyle, Katie DeVriese, and Christopher Schneider. 2010. "Emergent Qualitative Document Analysis.” Pp. 127-154 in Handbook of Emergent Methods, edited by S. N. Hesse-Biber and P. Leavy. New York: Guilford Press.

Anderson, Wayne P. and William R. Holcomb. 1983. “Accuses Murderers: Five Mmpi Personality Types.” Journal of Clinical Psychology 39(5):761-768.

Barnett, Vic and Toby Lewis. 1994. Outliers in Statistical Data, Vol. 3. New York: Wiley.

Belfrage, Henrik and Mikael Rying. 2004. "Characteristics of Spousal Homicide Perpetrators: A Study of All Cases of Spousal Homicide in Sweden 1990-1999." Criminal Behaviour and Mental Health 14(2):121-133.

Bijleveld, Catrien and Paul Smit. 2006. "Homicide in the Netherlands: On the Structuring of Homicide Typologies." Homicide Studies 10(3):195-219.

Bowen, Glenn A. 2009. "Document Analysis as a Qualitative Research Method.” Qualitative Research Journal 9(2):27-40.

Brad, Curtis A., Richard B. A.Coupland, and Mark E. Olver. 2014. “An Examination of Mental Health, Hostility, and Typology in Homicide Offenders.” Homicide Studies 18(4):323-341.

Brottsförebyggande rådet. 2015. "Konstaterade Fall Av Dödligt Våld - Statistik För 2014." Stockholm: Brottsförebyggande rådet. 
Canter, David V. 2011. "Resolving the Offender 'Profiling Equations' and the Emergence of an Investigative Psychology." Current Directions in Psychological Science 20(1):5-10.

Chaiken, J. M. and M. R. Chaiken. 1990. "Drugs and Predatory Crime.” Pp. 203-239 in Crime and Justice, Vol. 13, edited by M. Tonry and J. Q. Wilson. Chicago: University of Chicago Press.

Cohen, Mark A. and Alex R. Piquero. 2009. "New Evidence on the Monetary Value of Saving a High Risk Youth." Journal of Quantitative Criminology 25(1):25-49.

Cornell, Dewey G. 1990. "Prior Adjustment of Violent Juvenile Offenders.” Law and Human Behavior 14(6):569-577.

Crabbé, An, Stef Decoene, and Hans Vertommen. 2008. "Profiling Homicide Offenders: A Review of Assumptions and Theories." Aggression and Violent Behavior 13(2):88-106.

Decker, Scott H. 1993. "Exploring Victim-Offender Relationships in Homicide: The Role of Individual and Event Characteristics." Justice Quarterly 10(4):585-512.

- 1996. "Deviant Homicide: A New Look at the Role of Motives and Victim-Offender Relationships." Journal of Research in Crime and Delinquency 33(4):427-449.

Dobash, R. Emerson, Russell P. Dobash, and Kate Cavanagh. 2009. “'Out of the Blue': Men Who Murder an Intimate Partner." Feminist Criminology 4(3):194-225.

Domstolsverket. 2007. Domstolsverkets Föreskrifter Om Sammanställning Och Utskrift Av Vissa Uppgifter I Tingsrätt Och Hovrätt Inför Gallring I Vera. Domstolsverkets författningssamling DVFS 2007:7.

Ekström, Emma, Annika Eriksson, Lars Korsell, and Daniel Vesterhav. 2012. "Brottslighet Och Trygghet I Malmö, Stockholm Och Göteborg: En Kartläggning.” Stockholm: Brottsförebyggande rådet.

Esbensen, Finn-Aage and David Huizinga. 1993. "Gangs, Drugs, and Delinquency in a Survey of Urban Youth." Criminology 31(4):565-589.

Farrington, David P. and Sandra Lambert. 2010. "Predicting Offender Profiles from Offense and Victim Characteristics.” Pp. 135-167 in Criminal Profiling - International Theory, Research, and Practice, edited by R. N. Kocsis. New Jersey: Humana Press.

Fazel, Seena and John Danesh. 2002. "Serious Mental Disorder in 23000 Prisoners: A Systematic Review of 62 Surveys.” The Lancet 359:545-550.

Forsyth, Craig J. 2015. "Posing: The Sociological Routine of a Serial Killer." American Journal of Criminal Justice 40 (4):861-875.

Gabor, Thomas and Ellen Gottheil. 1984. "Offender Characteristics and Spatial Mobility: An Empirical Study and Some Policy Implications.” Canadian Journal of Criminology 26:267-281.

Gillies, Hunter. 1976. "Homicide in the West of Scotland." The British Journal of Psychiatry 128(2):105-127.

Gottfredson, David, David Wilson, and Stacey Skroban-Najaka. 2006. “School-Based Crime Prevention.” Pp. 56-164 in Evidence-Based Crime Prevention, edited by L. W. Sherman, D. P. Farrington, B. C. Welsh, and D. L. MacKenzie. New York: Routledge.

Gottfredson, Michael and Travis Hirschi. 1990. A General Theory of Crime. Stanford, CA: Standford University Press. Gottlieb, Peter, Peter Kramp, Anne Lindhardt, and Otto Christensen. 1990. "Social Background of Homicide." International Journal of Offender Therapy and Comparative Criminology 34(2):115-129.

Grubesic, Tony H. and Alan T. Murray. 2001. "Detecting Hot Spots Using Cluster Analysis and Gis.” Fifth Annual International Crime Mapping Research Conference 26.

Haggerty, Kevin D. 2009. "Modern Serial Killers." Crime, Media, Culture 5(2):168-187.

Hartigan, J. A. 1978. “Algorithm as 136: A K-Means Clustering Algorithm.” Applied Statistics 28(1):100-108.

Hawkins, Douglas M. 1980. Identification of Outliers, Vol. 11. London: Chapman and Hall

Hindelang, Michael J. and Joseph G. Weis. 1972. "Personality and Self-Reported Delinquency: An Application of Cluster Analysis." Criminology 10(3):268-294.

Holmes, Ronald M., James De Burger, and Stephen T. Holmes. 1988. "Inside the Mind of the Serial Murder." American Journal of Criminal Justice 13(1):1-9.

Holmes, Ronald M. and Stephen T. Holmes. 2009. Profiling Violent Crimes-An Investigative Tool. Thousand Oaks, CA: SAGE.

Howitt, Dennis. 2009. Introduction to Forensic \& Criminal Psychology. Harlow: Pearson Education.

Jensen, Gary F. and David Brownfield. 1986. "Gender, Lifestyles, and Victimization: Beyond Routine Activity." Violence and Victims 1(2):85-99.

Johnson, S. C. 1967. "Hierarchical Clustering Schemes." Psychometrika 32(3):241-254.

Kalichman, Seth C. 1988. "Empirically Derived Mmpi Profile Subgroups of Incarcerated Homicide Offenders." Journal of clinical psychology 44(5):733-738.

King, Roy D. and Emma Wincup. 2008. “The Process of Criminological Research.” Pp. 13-44 in Doing Research on Crime and Justice, edited by R. D. King and E. Wincup. New York: Oxford University Press.

Kocsis, Richard N. 2003. "Criminal Psychological Profiling: Validities and Abilities." International Journal of Offender Therapy and Comparative Criminology 47(2):126-144.

Langevin, Ron, D. Paitich, B. Orchard, L. Handy, and A. Russon. 1982. "Diagnosis of Killers Seen for Psychiatric Assessment." Acta Psychiatrica Scandinavica 66(3):216-228. 
Langevin, Ron and Lorraine Handy. 1987. "Stranger Homicide in Canada: A National Sample and a Psychiatric Sample." The Journal of Criminal Law and Criminology 78(2):398-429.

Liem, Marieke, Soenita Ganpat, Sven Granath, Johanna Hagstedt, Janne Kivivuori, Martti Lehti, and Paul Nieuwbeerta. 2013. "Homicide in Finland, the Netherlands, and Sweden: First Findings from the European Homicide Monitor." Homicide Studies 17(1):75-95.

Loeber, Rolf, Dustin Pardini, D. Lynn Homish, Evelyn H. Wei, Anne M. Crawford, David P. Farrington, Magda Stouthamer-Loeber, Judith Creemers, Steven A. Koehler, and Richard Rosenfeld. 2005. "The Prediction of Violence and Homicide in Young Men." Journal of Consulting and Clinical Psychology 73(6):1074-1088.

Loftin, Colin, David McDowall, Karise Curtis, and Matthew D. Fetzer. 2015. "The Accuracy of Supplementary Homicide Report Rates for Large Us Cities.” Homicide Studies 19(1):6-27.

Malmö tingsrätt. 2010. Beskrivning Av Malmö Tingsrätts Allmänna Handlingar Enligt 4 Kap 2 \$ Offentlighets Och Sekretesslagen (2009:400).

Malterud, Kirsti. 2009. Kvalitativa Metoder I Medicinsk Forskning. Lund: Studentlitteratur.

Meier, Robert F. and Terance D. Miethe. 1993. "Understanding Theories of Criminal Victimization." Crime and Justice 17:459-499.

Messner, Steven F. and Richard Rosenfeld. 1999. "Social Structure and Homicide." Pp. 27-41 in Homicide: A Sourcebook of Social Research, edited by M. D. Smith and M. A. Zahn. Thousand Oaks: SAGE.

Miller, Ted R., Mark A. Cohen and Brian Wiersema. 1996. "Victim Costs and Consequences: A New Look." US Department of Justice. Retrieved from https://www.ncjrs.gov/pdffiles/victcost.pdf

Neema, Isak and Dankmar Böhning. 2010. "Improved Methods for Surveying and Monitoring Crimes through Likelihood Based Cluster Analysis." International Journal of Criminology and Sociological Theory 3(2):477-495.

Palermo, George B. 2010. "Homicidal Syndromes: A Clinical Psychiatric Perspective." Pp. 3-26 in Criminal Profiling: International Theory, Research, and Practice, edited by R. N. Kocsis. Clifton, NJ: Humana Press

Pettersson, G. and A. Eriksson. 2013. “Onaturliga Dödsfall Måste Utredas Bättre-Risk Att Brott Missas-Granskning Av Polisens Och Sjukvårdens Dödsfallshandläggning I Tre Län.” Läkartidningen 111(48):2160-2162.

Pridemore, William Alex. 2006. "An Exploratory Analysis of Homicide Victims, Offenders, and Events in Russia." International Criminal Justice Review 16(1):5-23.

Riksarkivet. 2010. Riksarkivets Myndighetsspecifika Föreskrifter Om Gallring Och Annan Arkivhantering. RA-MS 2010 :3 Omtryck.

Rosenbaum, Milton and Binni Bennett. 1986. "Homicide and Depression.” American Journal of Psychiatry 143(3):367-370.

Rying, Mikael. 2003. "Dödlgt Våld I Kriminalstatistiken.” Vol. 2003/4. Stockholm: Brottsförebyggande rådet.

Salfati, Gabrielle and David Canter. 1999. "Differentiating Stranger Murders: Profiling Offender Characteristics from Behavioral Styles." Behavioral Sciences and the Law 17:391-406.

Savage, Joanne. 2009. "Understanding Persistent Off Ending: Linking Developmental Psychology with Research on the Criminal Career." Pp. 3-36 in The Development of Persistent Criminality, edited by J. Savage. New York: Oxford University Press.

Scott, P. D. 1973. "Fatal Battered Baby Cases.” Medicine, Science and the Law 13(3):197-206.

Sparrow, Malcolm K. 1991. "The Application of Network Analysis to Criminal Intelligence: An Assessment of the Prospects." Social Networks 13(3):251-274.

Teplin, Linda A. 1984. "Criminalizing Mental Illness: The Comparative Arrest Rate of the Mentally Ill.” American Psychologist 39(7):794-803.

Tita, George and Elizabeth Griffiths. 2005. "Traveling to Violence: The Case for a Mobility-Based Spatial Typology of Homicide." Journal of Research in Crime and Delinquency 42(3):275-308.

Torrey, Edwin Fuller. 2011. "Stigma and Violence: Isn't It Time to Connect the Dots?" Schizophrenia Bulletin 37 (5):892-896.

Ward, Joe H. 1963. "Hierarchical Groupings to Optimize an Objective Function." Journal of the American Statistical Association 58(301):234-244.

Wesley, Jared J. 2010. “Qualitative Document Analysis in Political Science.” Vrije Universiteit, Amsterdam.

Zahn, Margaret A. and Philip C. Sagi. 1987. "Stranger Homicides in Nine American Cities." Journal of Criminal Law and Criminology 78(2):377-397. 